\section{Critical Thinking Competence and its Impact on Acquisition of Basic Principles of Enterpreneurship Among Business Students in Latvia}

\author{
Iveta Linina
}

Turiba University

Velga Vevere

EKA University of Applied Sciences

$\Gamma$ crossef http://dx.doi.org/10.5755/j01.eis.1.15.29248

Critical thinking is mental process of analysis and evaluation of information. The source of information can be experience, reflection, observation, communication, etc., as well as study process. Business education is based on the ability to navigate the market situation and make informed decisions. The aim of the research is to determine correlation between business students information processing skills according to certain criteria and students' self-evaluation of their information processing skills. Based on this, the authors of the investigation study the theoretical basis of critical thinking with the monographic or descriptive method, with the help of a questionnaire assess students' ability to critically evaluate the situation and make decisions based on it. This study will provide an understanding the need for critical thinking and its development in the process of business education. Two research questions are put forward: (1) What is the self-assessment of critical thinking skills by the business students?(2) What are the differences between the self-assessment and the assessment according to the proposed criteria? In the result, the authors conclude that by studying the importance of critical thinking in educating business students, it is possible to increase market understanding and decision-making competence for students. Critical thinking is the skills of business students to start a successful business.

KEYWORDS: critical thinking; critical thinking in business; information assessment; $21^{\text {st }}$ century skills; RED model for critical thinking.

Globalization of the market is increasingly affecting companies, forcing them to seek solutions for competitiveness and development. The development of the company is based on the ability to orientate in the market situation and to make informed decisions. Decision making process, on its turn, is based on the ability to critically evaluate and process information. This calls for a special type of skills, the one of critical thinking - mental process of analysis and evaluation of information, recognition of the fake content, misleading data, etc. The source of information can be experience, reflection, observation, communication, etc., as well as study process. According to the research of Pearson Education (2013), the highest rated skills today are good analysis and problem-solving skills; good judgment and decision making; good overall job performance; the ability to evaluate the quality of information presented; creativity; job knowledge; and the potential to move up within the organization. Critical thinking skills, perhaps more than any other business skill set, can make the difference between success and failure. Business education
EIS 15/2021

Critical Thinking Competence and its Impact on Acquisition of Basic Principles of Enterpreneurship Among Business Students in Latvia

Submitted 01/2021

Accepted for publication 06/2021

\section{Abstract}

\section{Introduction}

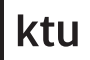

1922

European Integration Studies No. 15 / 2021, pp. 47-54 doi.org/10.5755/j01.eis.1.15.29248 
Literature

Review plays a special role in developing critical thinking skills. The aim of the research is to determine correlation between business students information processing skills according to certain criteria and students' self-evaluation of their information processing skills. In order to achieve the aim, the following tasks were set:

1 To analyze the essence of critical thinking and the theoretical basis of its formation.

2 To determine the level of critical thinking of business students.

In order to assess the level of critical thinking of business students, the following limitations have been set: the problem is studied mainly from methodological aspect and the age of the respondent of the survey is not taken into account. The research period was from January 1, 2021 to March 1, 2021. The following research methods have been used: the logical-constructive method for the literature review and creation of conceptual framework; the business students' survey $(n=276)$ applying 10-point Likert scale. The authors of the current research are daily involved with these issues being professors at the private universities in Latvia, teaching such subjects as critical thinking, problem solving, international marketing and research methodology to business students of the bachelor, master and doctoral levels.

There exists a variety of definitions of critical thinking depending on the field of application and its functions. Some value the reasoning process specific to critical thinking, while others emphasize the outcomes of critical thinking, for decision making or problem solving. For the purpose of the current research we employ a definition proposed by the Foundation for Critical Thinking that describes the critical thinking as the "intellectually disciplined process of actively and skilfully conceptualizing, applying, analysing, synthesizing or evaluating information gathered from, or generated by, observation, experience, reflection, reasoning, or communication, as a guide to belief and actions" (The Foundation for Critical Thinking, 1987). This definition comprises, in our opinion, the vital characteristics of this thinking mode, namely, the acquired (taught) abilities to work with information and apply results of reflection in the practice. In addition, the critical thinking involves the art of argument creation. This process is thoroughly described by T. Bowel and G. Kemp in their joint book "Critical thinking: a concise guide" (Bowell \& Kemp, 2020). The authors argue that it is very important to tell whether an argument is being given, exactly what the argument is about, and whether one ought to be persuaded by it.

R. Paul and L. Elder (2019) present a list of the characteristics of critical thinkers. These characteristics include the following activities: raising vital questions and problems, formulating them clearly and precisely; gathering and assessing relevant information, using abstract ideas to interpret it effectively; coming to well-reasoned conclusions and solutions, testing them against relevant criteria and standards; thinking open-mindedly within alternative systems of thought, recognizing and assessing as need be, their assumptions, implications, and practical consequences; and, finally, communicating effectively with others in figuring out solutions to complex problems. Moreover, critical thinking requires the use of self-correction and monitoring to judge the reasonableness of thinking as well as reflexivity. Thus, critical thinking ability can be viewed as one of the most important components in 21 st century skill roadmap alongside with communication and collaboration, innovation, media literacy, technology literacy, productivity and accountability, leadership and responsibility (Chu et al., 2017). Critical thinking was not only the first among the 21 st century skills but is the foundation for three other essential 21 st century skills: communication, collaboration, and creative thinking (Dwyer et al., 2015) These skills have been called "the four C's.

D. F. Halpern \& H. R. Riggio H. R. (2013), Eggers and others (2017), Bell and Loon (2015) focus on the outcome or utility aspect of critical thinking, in that critical thinking is conceptualized as a 
tool to facilitate decision making or problem solving in everyday life and business. Thus, business leaders take major actions every day, from hiring and firing to reviewing financial earnings reports, participating in board meetings and handling public relations crises. These are the precise areas in which critical thinking comes into play, as business leaders use this skill to make tough decisions, such as letting an employee go or issuing a press release when scandal threatens to tarnish a company's reputation (Karr, 2009). Today's business environment calls for leaders' ability to change, rethink and prepare for mobility, innovation, flexibility, agility, and change, as well as to work in a socially networked society, where new and emerging technologies continuously increase global communications ( $\mathrm{Li} \& \mathrm{Ma}$, 2017). Advancement of the new technologies, in its turn, requires particular skills to find information inside and outside the organization, to organize and process it avoiding traps of misinformation. Leaders (executives) should encourage all members of the organization to exercise critical thinking within the organization stressing that these particular skills would help in their career advancement within organization and in their overall contribution to the organization's success (employees want to be identified with a successful organization and a successful and professional career).

S. Natale \& F. Ricci (2006) and F. Ricci (2014) write about necessity to integrate critical thinking within the workplace by creating an awareness of the importance of critical thinking within each schedule of events, group meetings, planning, and project management coordination, analysis of financial reports, and organizational trends and projections. This would lead to building a team of administrators and employees with the ability to use critical thinking techniques through self-directed leadership and an expansion of the pool of leaders ready to take on new and creative organizational activities as a result of becoming good decision makers and problem solvers. Chartrand, Ishikawa \& Flanigan (2009) in their report admit that people who score well on critical thinking assessment are also rated by their supervisors as having good problem solving skills, good judgement and decision making abilities, creativity, the ability to evaluate information, etc. All in all, critical thinking process is being described as the Pearson's RED model, where R stands for the recognition of assumption (ability to separate fact from opinion); $\mathrm{E}$ - for the evaluation if arguments (analysing information objectively and accurately, questioning the quality of supporting evidence, and understanding how emotion influences the situation); and $D$ delineates the drawing conclusions (bringing diverse information together to arrive at conclusions that logically follow from the available evidence). At the same time, Elicor (2017) argues that critical thinking treated as a normative principle and balanced with a pragmatic orientation provides a rational framework for resolving conflicts.

Other authors put their stress upon teaching and educational aspects and inclusion of the dedicated course in the curriculum. Because success in our technically advanced society requires critical thinking competence, and because education is the principal means of preparing students for an active and responsible life, it is imperative that educational establishments focus on fostering and developing of critical thinking skills. S. A. Nonis and G. I. Hudson (2019) write about the developing skills of marketing students by the means of including specific themes and practical tasks in different courses (such as, marketing, management, market research, etc.). Among the recent studies we can mention the ones by R. Andrews (2015), R. Barnett (2015), K. Thomas and B. Lok (2015). All in all, these studies exemplify the need for critical thinking skills in business education.

Yet other researchers are engaged in the problem of assessment of the level of students' critical thinking, here we can mention such authors as A. S. Ünsar and E. Engin (2013), M. Karakoc (2016), B. Critchley (2011,; A. Khalifa (2009), T. Laurer (2005), S. K. Bandyopadhyay and J. Szostek (2018), F. W. Brown \& A Bielinska-Kwapisz (2015). 
Within the framework of this research, in order to find out the students' ability to obtain information and critically evaluate it, a traditional method was used - a survey was organized with the help of a questionnaire. The survey was conducted in three Latvian higher education institutions among students studying in the business management program to identify the students' ability to distinguish false information from the facts. Preparing to use this method involves certain steps. Let us characterize them briefly.

First, determining the standardization and degree of openness of the questionnaire. Taking into account the purpose of the survey and the characteristics of the respondents, the authors of the paper chose a standardized open questionnaire. This means that all respondents were offered the same questions in the same order, which ensures an objective comparison of answers. The questions were selected with one answer version according to the 10-point Likert scale, as well as multiple choice questions.

Second, determining the surveying method. The authors of the paper chose the following option - the survey was created in the Google Forms. Questionnaires were distributed via e-mails using the personal contacts of the authors, as well as placed in the Facebook platform. Thus, the sampling method can be deemed as one of the snowball type; the census - a total number of all Latvian business students in 2019 . At the $95 \%$ reliability level and the $5 \%$ margin of error, the minimum sample size was calculated of 258 respondents (Arhipova \& Bālina, 2006), 276 answers were recognized as valid for the current research.

Third, determining the ways students' obtain information and testing the questionnaire. At the same time, it is very important to make sure that the respondents have the necessary information to answer the questions raised. In order to do that focus group discussions and a pilot research were carried out.

Fourth, question formulation according to the principles: use of simple words and sentences, avoiding ambiguous words and questions, avoiding prompting questions, hidden alternatives, etc. (Payne, 1978; Erdos, 1983).

Fifth, sequence of questions. The sequence of questions is also an important step, as it affects the respondent's interest in answering questions accurately. In order to avoid mistakes, the authors followed the special recommendations: at first general questions were asked, but then specific questions; relatively difficult questions were placed in the of the questionnaire; questions related to one theme have to be completed before moving on to the next theme.

Sixth, determining the form of the answer. In order to be able to provide a quantitative assessment and perform an appropriate analysis, the authors used a Likert scale with a ten-point rating, where 0 stands for no rating and 10 - very high rating. Besides that, part of the questions contained multiple answer possibilities. The questionnaire consisted of multiple choice questions regarding information sources; trust in public leaders (naming particular personalities; public persons' responsibility for possible consequences; number of personal social media profiles; reading fiction books apart from the school assignments; opinion about what advertisement is. Besides that, there were also such questions: "Latvia public media distribute false information", "Information distribution in Latvia is in hands of governing circles", "European and public media distribute false information", "Information source influences information reliability", "To what extent do you believe that Covid-19 is an imagined affair?" "To what extent you judge content by the title alone", "To what extent do agree that in case of doubt you look for additional information?" and others. Two questions were directly related to students' self-evaluation - "Evaluate your personal interestedness in social-political processes in Latvia" and "Evaluate your ability to distinguish false information from true information".

Seventh, use of statistical methods for processing and analysis of student survey results. Using the SPSS computer program, the authors calculated the following indicators: arithmetic mean 
$\left(X^{-}\right)$; arithmetic mean standard error; median (Me); mode (Mo); amplitude of variation; standard deviation (Kristapsone et al., 2016). For questions with possible multiple answers, the percentage of answers in the total sum of answer options was calculated. In order to find out whether there is a connection between the respondents' self-assessment and other factors, correlation coefficients were calculated (Arhipova, Bāliṇa, 2006).

Two research questions are put forward:

" RQ1: What is the self-assessment of critical thinking skills by the business students?

" RQ2: What are the differences between the self-assessment and the assessment according to the proposed criteria?

The responses were further processed and analyzed.

First, the issue of students' self-assessment in recognizing false information was addressed (see Table 1). In this question, students rated their skills in recognizing false messages on a 10-point scale, where 0 meant that students were not able to distinguish false information from the real one at all, and 10, where they were always able to do so.

\begin{tabular}{|l|c|c|c|c|c|c|}
\hline $\begin{array}{c}\text { Assessment } \\
\text { criterion }\end{array}$ & $\begin{array}{c}\text { Arithmetic } \\
\text { mean }\end{array}$ & $\begin{array}{c}\text { Arithmetic mean } \\
\text { standard error }\end{array}$ & Median & Mode & $\begin{array}{c}\text { Amplitude of } \\
\text { variation }\end{array}$ & Standard deviation \\
\hline $\begin{array}{l}\text { Recognition of } \\
\text { false information } \\
\text { (student's self- } \\
\text { evaluation) }\end{array}$ & 7.22 & 0.85 & 8.00 & 8.00 & 8.00 & 2.54 \\
\hline
\end{tabular}

Analyzing data obtained, it can be concluded that students evaluate their skills in recognizing false information quite high, because the arithmetic mean is 7.22. But we look at the range of variations, it appears large. As the median shows, the most common grade was 8 , but no student rated herself with 0 and 1 .

In order to find out whether there is a correlation between the respondents' self-assessment and the factors that indicate the reasons for not recognizing false information, a correlation coefficient was calculated. The authors' calculations of the correlation coefficient between the respondents' self-assessment (on a 10-point scale) and three factors - limited sources of true information, belief in populist personalities and recognition of world-renowned Latvian scientists showed that the correlation existed, but it was rather weak. The negative correlation coefficient indicates that when one indicator increases, another decreases, but the positive correlations means, that if one increases another increases as well. The very weak and weak correlations mean that level of a student's self-evaluation has no bearing on factors that may affect his or her ability to recognize false information or the student's own ability to objectively assess himself or herself in relation to recognition of false information (see Table 2).

\begin{tabular}{l|c}
\hline $\begin{array}{l}\text { Factors that make it possible to recognize false } \\
\text { information }\end{array}$ & $\begin{array}{c}\text { Student's self-evaluation in recognizing false } \\
\text { information }\end{array}$ \\
\hline Number of information sources used & -0.156 \\
\hline Belief in populistic personalities & 0.104 \\
\hline Ability to recognize world renowed Latvian scientists & -0.121 \\
\hline
\end{tabular}

\section{Results and discussion}

Table 1

Students' self-assessment in recognizing false information

Source: Authors'

Table 2

Correlation coefficients that show the relationship between a student's selfassessment in recognizing false information and factors that indicate a lack of ability

Source: Authors' 
Figure 1

Students' desire to seek additional information in case of doubt (Source: Authors')

\section{Conclusion}

Calculation of the correlation coefficients demonstrate that the higher the student's self-esteem, the less information sources he/she uses. Belief in highly populist well-known personalities, there is a weak but positive correlation with high self-esteem. A similar situation is observed regarding the recognition of scientists. The fewer scientists are recognized, the higher degree of students' self-evaluation regarding their skills in recognizing false information. These correlation coefficient calculations show that students have great difficulty in assessing their ability to distinguish false information from true information objectively.

Respondents were asked if in case they have doubts about credibility of information, they look for additional information (see Figure 1).

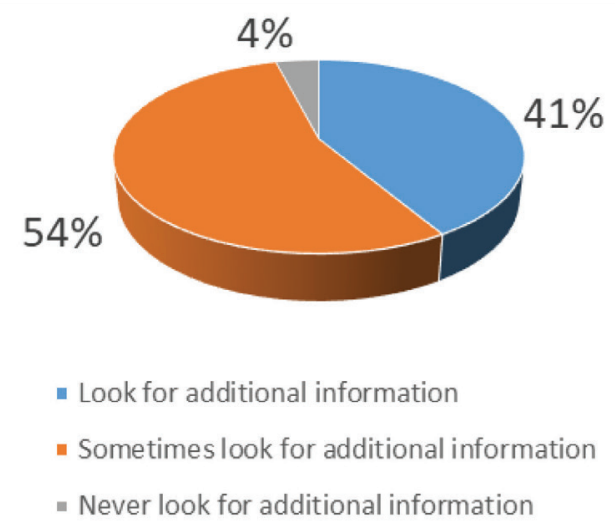

The answers to this question made it possible to find out that in the case of doubts about the truthfulness of the information $96 \%$ students are ready to look for additional information.

1 As a result of the survey it was found out that students, when evaluating their skills to distinguish false information from the true one, have assessed themselves relatively high, with the arithmetic mean of 7.22 .

2 The calculations of the correlation coefficient demonstrates that students are more likely to be unable to assess their skills in recognizing false information; the more limited the student's information sources are and the less he is able to recognize world-class Latvian scientists, the higher he evaluates his skills in recognizing false information. As well as those whose self-esteem is higher have higher trust level in populistic personalities. But because the correlation is weak, this conclusion cannot be fully applied to all respondents. Summarizing all the information obtained in the study, it can be concluded that students studying business have problems with objective self-assessment in recognizing false information, but the positive is that students are still ready to look for (96\%) additional information in the case of doubt.

Andrews R. (2015). Critical Thinking and/or Argumentation in Higher Education. M. Davies \& R. Barnett (Eds.), In Palgrave Handbook of Critical Thinking in Higher Education (pp. 49-62). New York: Palgrave Macmillan. https://doi.org/10.1057/9781 137378057_3

Arhipova I. \& Bālina S. (2006). Statistics in Economy and Business [Statistika ekonomikā un biznesā] ( $p$. 362). Riga: Datorzinību centrs.
Bandyopadhyay S. K. \& Szostek J. (2018). Thinking critically about critical thinking: Assessing critical thinking of business students using multiple measures. The Journal of Education for Business, 94(4), 1-12. https://doi.org/10.1080/08832323.2018.1524355

Barnett R. (2015). A Curriculum for Critical Being. M. Davies \& R. Barnett (Eds.), In Palgrave Handbook of Critical Thinking in Higher Education (pp. 
63-76). New York: Palgrave Macmillan. https://doi. org/10.1057/9781137378057_4

Bell R. and Loon M. (2015). The impact of critical thinking disposition on learning using business simulations. International Journal of Management Education, 13(2), 119-127. https://doi.org/10.1016/j. ijme.2015.01.002

Bowell T. \& Kemp G. (2020). Critical thinking: A Concise Guide (p. 348). London and New York: Routledge. https://doi.org/10.4324/9781351243735

Brown F. W. \& Bielinska-Kwapisz A. (2015). Understanding the Nature and Determinants of Critical Thinking Among Senior Business Undergraduate Students. Journal of Education for Business, 90(7), 359-368. https://doi.org/10.1080/08832323.2015.1068156

Chartrand J., Ishikawa H. \& Flanigan S. (2009). Critical thinking means business: Learn to apply and develop the NEW \#1 workplace skill. Pearson Education. Retrieved 22 March, 2021 from http://www.talentlens. com/en/downloads/whitepapers/Pearson_TalentLens_Critical_Thinking_Means_Business.pdf

Chu S. K. W. et. al. (2017). 21st Century Skills Development Through Inquiry-Based Learning ( $p$. 222). Singapore: Springer Science+Business Media. https://doi.org/10.1007/978-981-10-2481-8

Critchley B. (2011). Critical Thinking in Business Education. Investigations in university teaching and learning, 7, 5-15.

Dwyer C. P., Boswell A. \& Elliott M. A. (2015). An Evaluation of Critical Thinking Competencies in Business Settings. Journal of Education for Business, 90, 260-269. https://doi.org/10.1080/088323 23.2015 .1038978

Eggers F, Lovelace K. J., and Kraft F. (2017). Fostering creativity through critical thinking: The case of business start-up simulations. Creativity and Innovation Management, 26(3), 266-276. https://doi. org/10.1111/caim.12225

Elicor P. P. (2017). Critical Thinking and Community of Inquiry within Professional Organizations in the Developing World. Journal of Human Values, 23, 13 - 20. https://doi.org/10.1177/0971685816673479

Erdos P. L. (1983). Professional Mail Surveys (p. 304). Melburne, Fla.: Robert E.Krieger Publishing.

Halpern D. F. \& Riggio H. R. (2013). Thinking Critically About Critical Thinking: A Workbook to Accompany Halpern's Thought \& Knowledge (p. 256). London and New York: Routledge. https://doi. org/10.4324/9780203393543

Karakoc M. (2016). The Significance of Critical Thinking Ability in terms of Education. International Journal of Humanities and Social Science, 6(7), 81-84.
Karr S. S. (2009). Critical thinking: a critical strategy for financial executives: as accounting standards become more principles-based and global in nature, emphasizing analysis and creative thinking could lead to greater organizational success. Financial Executive, 25(10), 58+.

Khalifa A. (2009). Rethinking the Current Dominant Approach to Business School Strategy. European Business Review, 22(6), 591-607. https://doi. org/10.1108/09555341011082907

Kristapsone S. et. al. (2016). Research. Theoriy and Practice [Pētniecība. Teorija un prakse] (p. 546). Rĩga: RaKa.

Laurer T. (2005). Teaching Critical Thinking Skils Using Course Content Material: a reversal of roles. Journal of College Science Teaching, 34(6), 34-37.

Li XQ. \& Ma L. (2017). Research on the Relationship between Critical Thinking and Employee Innovation Behavior. Proceedings of the 2017 International Conference on Sports, Arts, Education and Management Engineering (Saeme 2017), 105, 144-147. https:// doi.org/10.2991/saeme-17.2017.20

NataleS. \& Ricci F. (2006). Critical thinking in organizations. Team Performance Management, 12(7), 272278. https://doi.org/10.1108/13527590610711822.

Nonis S. A. \& Hudson G. I. (2019). Developing and assessing critical thinking skills in marketing students: The power of making explicit problem-solving processes. Journal of Education for Business, 94(3), 195203. https://doi.org/10.1080/08832323.2018.1504737

O'Neil, J. M., \& Egan, J. (1992). Men's and women's gender role journeys: Metaphor for healing, transition, and transformation. In B. R. Wainrib (Ed.), Gender issues across the life cycle (pp. 107-123). New York: Springer.

Paul R. \& Elder L. (2019). Critical Thinking Tools for Taking Charge of Your Professional and Personal Life (p. 528). Upper Saddle River, New Jersey, Pearson Education, Inc.

Payne S. L. (1978). The Art of Asking Questions ( $p$. 249). Princeton: Princeton University Press.

Pearson Education. (2013). Research results. Retrieved March 19, 2021 from https://www.pearson. com/news-and-research/announcements/2014/02/ pearson-2013-results.html

Ricci F. (2014). Cultivating critical thinking within organizations. Proceedings of SOCIOINT14- International Conference on Social Sciences and $\mathrm{Hu}-$ manities, 67-74. Retrieved 15 February, 2021 from http://www.ocerints.org/Socioint14_e-publication/ papers/48.pdf 
The Foundation for Critical Thinking. (1987). Defining Critical Thinking. Retrieved 20 March, 2021 from https://www.criticalthinking.org/pages/defining-critical-thinking/766

Thomas K. \& Lok B. (2015). Teaching Critical Thinking: An Operational Framework. M. Davies \& R. Barnett (Eds.), In Palgrave Handbook of Crit-

\section{About the}

LININA IVETA

Dr. oec.

Turiba University

\section{Fields of interests}

Customer relationship marketing, critical thinking, marketing communications, sales management.

\section{Address}

68 Graudu street, Riga LV-1055, Latvia

+371226306922

iveta.linina@turiba. ical Thinking in Higher Education (pp. 93-106). New York: Palgrave Macmillan. https://doi. org/10.1057/9781137378057_6

Ünsar A. S. \& Engin E. (2013). A case study to determine critical thinking skills of university students. Procedia - Social and Behavioral Sciences, 75, 563 569,. https://doi.org/10.1016/j.sbspro.2013.04.061

\section{VEVERE VELGA}

Dr.phil.

EKA University of Applied Sciences

\section{Fields of interests}

Critical thinking, corporate social responsibility, business ethics, governance, marketing communications.

\section{Address}

1/5 Lomonosova street, Riga LV-1003, Latvia +37126463584

velga.vevere@gmail.com 